For citation:

Izvestiya Ural'skogo gosudarstvennogo gornogo universiteta [News of the Ural State Mining University]. 2016. Issue 2. pp. 86-90. удК 338:242.4

\title{
THE GUIDELINES FOR ECONOMIC VALUATION OF ECOSYSTEM SERVICES IN REGION
}

\author{
V. V. Yurak
}

\section{Методика экономической оценки экосистемных усиуг региона

\author{
В. В. Юрак
}

Исследование посвяшено проблеме разработки методических рекомендаций по экономической оценке экосистемных ускуг природного потенциала региона на основе концепции общей экономической ценности. Оценке поммежаяи экосистемные усиуги, отраженные в киассификации экосистемных ускуг из Мillennium Ecosystem Assessment. Обеспечивающие усиуги характеризуются как реаиизация ресурсных функций, т. е. представляют природные ресурсы. Они оцениваяись согласно методическим рекомендациям по экономической оценке природных ресурсов. Экономическая оценка регулирующих услуг происходила в несколько этапов: 1) анализ земельных угодий в рассматриваемом районе; 2) выделение угодий (соответствуюших экосистем), занимаюших наибольшую плошаљь в районе; 3) выявление наиболее важных экоусиуг Аля кажАого вида вылеленных угодий на основе экспертных оценок; 4) экономическая оценка экоуслуг (экологических ресурсов), относящихся к числу приоритетных. Анаяиз земельных угодий в рассматриваемом районе предполагает формирование структуры земель с выцелением: сельскохозяйственных угодий, земель, покрытых мревесно-кустарниковой растительностью, земель застройки, болотных земель, лесных земель; земель под водой, под Аорогами и прочих. Выхеление наиболее значимых экоусиуг осушествляется по результатам экспертного опроса специалистов, связанных профессионаяьно с решаемой проблемой. Уровень значимости предоставляемых усиуг оценивается экспертами в бамлах. ПодАерживающие усиуги необходимы мял сушествования самой экосистемы и оказания ею экосистемных усмуг, поэтому во избежание двойного счета подерживаюшие усууги не помлежаяи экономической оценке. Культурные услуги помеежат оценке как по формулам, так и путем проведения опросов о готовности населения платить за сохранение экосистемы и, как следствие, её духовных и религиозных ценностей. Аанные методические рекомендации апробированы на примере Березовского района ХМАО. Выполненные исслеАования сиужат основой мяя совершенствования методов оценки экосистемных усиуг, их систематизации, а также проведения экспресс-оценки природного потенциала мюбого анаяизируемого региона.

Киючевые слова: экосистемные услуги; концепция общей экономической ценности; природопользование; природо-ресурсный потенциаи региона.

Research is devoted to the problem of developing guidelines for the economic valuation of ecosystem services of natural potential of the region based on the concept of total economic value. We evaluate ecosystem services based on the classification of ecosystem services of the Millennium Ecosystem Assessment. Provisioning services are the realization of service functions or natural resources. Author evaluated provisioning services according to the methodical recommendations on the economic valuation of natural resources. Economic evaluation of regulatory services took place in several stages: 1) analysis of land in the area; 2) allocation of land (related ecosystems), occupying the largest area in the region; 3) identification of the most important ecosystem services for each type of land based on the ex pert assessments; 4) economic assessment of ecosystem services (environmenta resources) relating to the priority. Analysis of the land in this area involves the formation of structures with land allocation: agricultural land, land covered with trees and shrubs, building land, marsh lands, forest lands; land under water, roads and others. Highlighting the most important ecological services was performed by the results of the expert survey. Experts estimate the significance level of provided services in points. Supporting services are necessary for the existence of the ecosystems and its ecosystem services provision, so in order to avoid double counting supporting services are not the subject for economic assessment. Cultural services are the subject to assessment both by the formulas, and by carrying out surveys on the population's willingness to pay for the preservation of the ecosystem and, as a consequence, of its spiritual and religious values. These guidelines are approved at Berezovsky District (Khanty-Mansi Autonomous District (KhMAD), Russia). The studies provide the basis for improved methods for assessing ecosystem services, their classification, as well as the rapid assessment of any of the analyzed region.

Keywords: ecosystem services; the concept of total economic value; natural resource management; natural and resource potential of the region.

$\mathrm{N}$ atural conditions and resources, which are necessary for human life and activity, create natural and resource potential of the region. Natural and resource potential of any region is a specific set of conditions and environment resources (geosystems, landscapes), which ensures the existence of people and the needs for its business activities. The natural and resource potential correlated with the natural landscape consists of, first of all, those natural qualities and conditions that have a direct impact on the perceptions and the health state of people. These natural qualities and conditions compose the environmental potential of the area, characterizing the degree of comfort and favorable natural conditions for human life. Another part of the complex potential is the resource potential. It is the totality of the natural resources, which are used as natural resources (mineral, water, biota etc.) for industrial and agricultural production, recreation and other human activities [1].

For a long time humanity considered only a resource aspect of the natural potential of the territory, which led to its overexploitation, and as a con sequence, to the emergence of the environmental crisis on the planet. In this regard, the scientific community is concerned about the maintenance of the equilibrium of nature, which means the accounting of both components of the territory: environmental and resource. The set of methodical approaches of recourse part of the resource potential on the territory has already been formed and is described in detail in the research [2]:

1) methods based on the cost approach;

2) methods based on the evaluation of differential rent;

3) mixed modification cost and rental approach;

4) Scoring techniques;

5) methods based on the combination of score and rent estimates;

6) regulatory methods.

The process of developing different methods of accounting environmental aspect of natural proceeds in the scientific community, and in this regard, one should note the most current research directions of the theory of ecosystem services and the concept of total economic value. The origins of the theory of ecosystem services were formed in the late 70-ies of XX century. Researches of W. Westman and R. De Groot developing beneficial ecosystem functions as a service in order to increase public interest in the conservation of biodiversity $[3,4]$ laid the foundation of the theory of ecosystem services. In the 90 s of the last century the issues of economic valuation of ecosystem services are reflected in the works of foreign scientists R. Constanza and H. E. Daly [5], in the works of Russian scientists like S. N. Bobylev, N. N. Lukyanchikov, R. A. Perelet, I. M. Potravny [6], L. G. Mel'nik, E. V. Mishenin, Yu. Yu.Tunitsa, N. K. Shapochka etc. [7-10].

Ecosystem services are often associated with natural capital. There are two approaches to ecosystem services. In the first "wide" approach, all the functions of natural capital are ecosystem. The second approach considers the ecosystem services as one of the functions of natural capital - "narrow" approach. Four functions of natural capital can be distinguished:

1) resource - providing the natural resources of goods and services;

2) regulating - ecosystem / environmental services associated with providing various types of regulatory functions from nature: assimilation of pollution and waste, climate regulation and the water regime, the ozone layer, etc.;

3 ) the nature services connected with the aesthetic, ethical, moral, cultural, historical aspects - a kind of "spiritual" environmental services;

4) providing human health [6]

According to the "wide" interpretation, ecosystem services represent the whole range of goods and services provided by nature (all functions of natural capital). Therefore, the classification (Millennium Ecosystem Assessment, 2005 ) is used in the world practice focusing on the "wide" interpretation of ecosystem services, where the ecosystem services are divided into four groups: provisioning, regulating, cultural (directly affecting the people), and supporting (preserving other ecosystem services) $[11,12]$.

According to a "narrow" interpretation, ecosystem services are services that provide economic benefits for consumers of these services based on the nature providing the various kinds of regulatory functions. That means that only regulating service are in focus. Consumers of these services can be at the 


\begin{tabular}{|c|c|c|c|c|}
\hline \multicolumn{3}{|c|}{ Use value $A$} & \multicolumn{2}{|c|}{ Non-use value $B$} \\
\hline Direct $A_{1}$ & Indirect $A_{2}$ & Option $A_{3}$ & existence value $B_{1}$ & bequest value $B_{2}$ \\
\hline Provisioning services $\mathrm{O}$ & $\begin{array}{l}\text { Regulating services } P+ \\
\text { supporting services } \Pi\end{array}$ & \multirow{2}{*}{$\begin{array}{c}\text { Adjusted for the time value of } \\
A_{1} \text { и } A_{2} \text {, or Adjusted value } \mathrm{O} \\
\text { and } P+\Pi\end{array}$} & \multicolumn{2}{|c|}{ Cultural services $K$} \\
\hline $\mathrm{O}_{1}+\mathrm{O}_{2}+\mathrm{O}_{3}+\mathrm{O}_{4}+\mathrm{O}_{5}$ & $\begin{array}{c}p_{1}+p_{2}+p_{3}+p_{4}+p_{5}+n_{1}+n_{2} \\
+n_{3}+n_{4}\end{array}$ & & $\mathrm{~K}_{4}$ & $\mathrm{~K}_{1}+\mathrm{K}_{2}+\mathrm{K}_{3}$ \\
\hline
\end{tabular}

Figure 1. The structural distribution of ecosystem services according to the concept of total economic value.

local level (e.g., individual companies) or both at the regional and global levels - entire regions and countries. In the latter case we can point to global ecosystem services, such as absorption of $\mathrm{CO}_{2}$ by forests.

Along with the existing approaches to ecosystem assessment, the concept of total economic value is increasingly gaining the attention. This concept is the most promising in terms of the theory of value, ecosystem services and integrated assessment of natural and resource potential. This concept appeared at the end of the XX century in the work of D. W. Pearce, R. K. Turner, dating from 1990, that was the first introduction of a systematic approach to the problem of the economic assessment of the damage to ecosystems and the proposal of the concept of total economic value of natural resources. In the nowadays literature, there are slightly different variants of the structure of total economic value. One of the most popular models presented in the papers [13-17] is as follows: Total Economic Value $=$ use value + non-use value. Use value $=$ direct use value + indirect use value or ecological value + option value; non-use val$\mathbf{u e}=$ existence value + other types of non-use value including the bequest value.

Thus, it is important to note that the former understanding of the region assessment as a natural environment and the estimated reserves and resources do not meet modern requirements [18]. Therefore, scientific study needs further development or addition of the existing approaches to the assessment of environmental and natural resource potential of the region on the basis of the theory of value. This development or addition has to accumulate the modern realities and scientific research relating to ensure the equilibrium of nature, based on the ecosystem and social and economic approach, taking into account both environmental and resource component of natural resources. Therefore this article develops author's guidelines for the economic valuation of ecosystem services of natural potential of the region based on the total economic value strategy.

Author's guidelines are based on the following principles:

1 . The guidelines employ the classification of ecosystem services presented in the Millennium Ecosystem Assessment [11].

2. With regard to the structure of the total economic value with ecosystem services is as follows (Fig. 1).

3. The total economic value of ecosystem services (environmental resources) (TEV):

$A$ - use value; $B$ - non-use value.

$$
\mathrm{TEV}=\mathrm{A}+\mathrm{B},
$$

Non-use value $(A)$ :

$$
A=A_{1}+A_{2}
$$

$A_{1}$ - provisioning services; $A_{2}$ - regulating services $(P)$ and supporting services $(\Pi)$;

$$
A_{1}=\sum_{j=1}^{5} a_{i},
$$

$a_{i}-$ provisioning services $i$-type.

$$
P=\sum_{j=1}^{5} p_{j},
$$

$p_{j}$ - regulating services $j$-type.

$$
\Pi=\sum_{\mathrm{a}=1}^{4} n_{a},
$$

$n_{a}$ - supporting services $a$-type.

Non-use value (B):

$$
\mathrm{B}=\mathrm{K}=\mathrm{B}_{1}+\mathrm{B}_{2},
$$

$K$ - cultural services; $B_{1}$ - existence value; $B_{2}$ - bequest value.

$$
B_{2}=\sum_{b=1}^{3} k_{b}
$$

$k_{b}$ - ecosystem services that determine the value of the bequest value $b$-type.

Existence value $B_{1}$ is defined by recreation and ecotourism $K_{4}$

4. Providing services are described as the realization of resource functions. These services represent natural resources and are evaluated according to the methodical recommendations of the economic valuation of natural resources.
5. Economic evaluation of regulating services involves the following algorithm (Fig. 2).

6. Analysis of land in this area involves the formation of the land structure with allocation of agricultural land, land covered with trees and shrubs, building land, marsh lands, forest lands; land under water, roads and others. The base to this analysis is statistical report (Form 22-2).

7. Lands occupy the largest share allocated as a priority. Their total area should occupy more than $75 \%$ of the total area.

8. The selection process of the most important ecosystem services are performed by the results of the expert survey of professionals connected with solving these problems. The significance level of providing services is estimated by experts in points (with a decrease in the importance the value of points is reduced).

9. Supporting services are necessary for the existence of the ecosystems and its ecosystem services provision, so, in order to avoid double counting, supporting services are not the subject for economic assessment.

10. Regulating ecosystem services is proposed to estimate based on the formulas shown below. Depending on the type of ecosystems the indicators can be modified.

Regulation of air quality by forest ecosystem $p_{1}$

It is possible to define this ecosystem service can in several variants, both the ecosystem's ability to deposit carbon dioxide and to produce oxygen and also as the sum of these two components. The article chooses the sum of two components. Evaluation is made by the market price according to the classification of methods presented in the study [19].

$$
\mathrm{O} p_{1}=\sum_{i=1}^{n}\left(\sigma_{i} \times \mathrm{O}_{2 i} \times \amalg_{0}\right)+\sum_{i=1}^{n}\left(\sigma_{i} \times \mathrm{CO}_{2 i} \times p\right),
$$

$\mathrm{O} p_{1}$ - economic valuation of ecosystem services of regulating air quality by the forest ecosystem, rubles; $\sigma$ - forest area $i$-type of bonitet in the analyzed area regardless of the type of forest, ha; $\mathrm{O}_{2 i}$ - the amount of oxygen released by 1-hectare forest $i$-type of bonitet, ton (Table 1); $ц_{0}$ - the cost of 1 ton of $\mathrm{O}_{2}$ in 2016 ( 1 ton of $\mathrm{O}_{2}=10000$ rub./ton); $\mathrm{CO}_{2}$ - the amount of $\mathrm{CO}_{2}$ absorbed by 1 ha of forest $i$-type of bonitet, tons (Table 1); $p$ - fixed price of 1 ton of $\mathrm{CO}_{2}$ according to the Kyoto Protocol (10-50 dollars USA), rubles; $i-$ type of bonitet $(i=1, \ldots, n, n=4)$.

Regulation of air quality by marsh and pasture ecosystems $p_{1}$

Assessment of the value of ecosystem services is determined according to the proportional distribution of phytomass between forest ecosystem services, ecosystem services of marshes and pastures by market prices. According to the results of studies carried out in northern regions [20] we can point that the biological reserve of wild plants in relation to other types of herbaceous vegetation is about $20 \%$. The rest of herbaceous vegetation is distributed between forest and marsh ecosystems as a percentage ratio of 50:50. If we take phytomass of forest woody vegetation for $Y$, phytomass of wild grasses in the marshes for $Z$, and phytomass of common wild grasses for $X$, the final calculation of phytomass will be presented in Table 2 .

Table 1. Release of oxygen and the absorption of carbon dioxide per 1 ha of forest, ton/year.

\begin{tabular}{ccccc}
\hline $\begin{array}{c}\text { Bo- } \\
\text { nitet }\end{array}$ & Wide & $\begin{array}{c}\text { Total amount } \\
\text { of oxygen release }\end{array}$ & $\begin{array}{c}\text { The amount of } \\
\text { oxygen released } \\
\text { into the atmo- } \\
\text { sphere }\end{array}$ & $\begin{array}{c}\text { The amount of the } \\
\text { absorbed carbon } \\
\text { dioxide }\end{array}$ \\
\hline 1 & $0,8-0,9$ & $7-10$ & $3,5-5$ & $4,6-6,5$ \\
2 & $0,8-0,85$ & $5,5-7,6$ & $2,8-3,8$ & $3,5-4,9$ \\
3 & $0,65-0,75$ & $4,5-6,4$ & $2,2-3,2$ & $2,9-4,1$ \\
4 & $0,6-0,7$ & $3,6-5,2$ & $1,8-2,6$ & $2,8-3,4$ \\
\hline
\end{tabular}

"Provided that the $50 \%$ of biomass goes into the fall, which is required $50 \%$ of release oxygen for the oxidation process.

Regulation of climate by forest ecosystem $p_{2}$

One can calculate the economic assessment of the impact of changes that have occurred on the assessed forest area for a certain period (increase or decrease of the number of trees) to the formation of the climate of the planet based on previous studies, employing the cost method [21]. Every year the economic losses caused by natural disasters increase. According to the results 


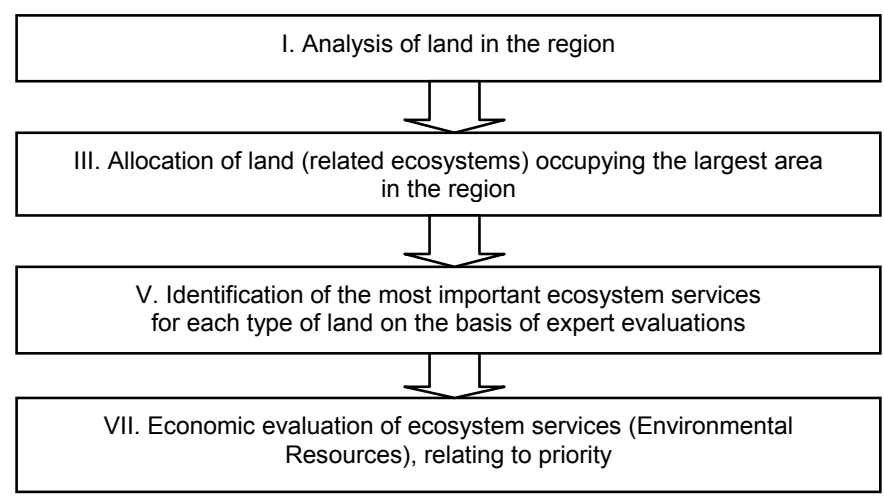

Figure 2. Algorithm of economic assessment of the regulating functions.

Table 2. The calculation of phytomass of ecosystems, tons.

\begin{tabular}{ccl} 
Forest ecosystem & Marsh ecosystem & \multicolumn{1}{c}{ Pasture ecosystem } \\
\hline$(Y+3 X-Z)$ & $(Z+2 X)$ & $\begin{array}{l}\text { It determines on the basis of the } \\
\text { explication of lands of the analyzed } \\
\text { area }\left(\kappa_{1} \text { and } \kappa_{2}\right)^{*}\end{array}$ \\
\hline
\end{tabular}

" $K_{1}$ and $K_{2}$ are territorial factors determined on the basis of the explication of lands of the analyzed area.

The value is defined via the proportional way based on Table 2 and $O p_{1}$

of the study [22], the economic damage caused by natural disasters in the $90 \mathrm{~s}$ is 3 times higher than the level of 80 s. According to several authors [23, 24], the total economic damage amounted more than 930 billion US dollars in the period from 2000 to 2009 , during only one year in 2010 - 222 bln dollars, and for the first 9 months of 2011 - more than 550 billion dollars. Estimates of the reduction of forest land on the planet are different - from $7 \mathrm{mln}$ ha to 19-23 mln ha per year.

For the purposes of economic assessment natural disasters can be divided into: - natural disasters (bringing direct economic losses):

- flood $\left(\mathrm{C}_{1}\right)$;

- earthquake $\left(\mathrm{C}_{2}\right)$;

- volcanic activity $\left(\mathrm{C}_{3}\right)$;

- tsunami $\left(\mathrm{C}_{4}\right)$;

- sea level rise $\left(\mathrm{C}_{5}\right)$;

- storms and hurricanes $\left(\mathrm{C}_{6}\right)$;

- tornado $\left(\mathrm{C}_{7}\right)$;

- forest fires $\left(\mathrm{C}_{8}\right)$;

- anomalies and natural disasters, the damage from which cannot be evaluated economically, but have an impact on ecosystems on the planet, including the frequency and scale of natural disasters (such phenomena as the displacement of the magnetic poles, the Earth's axis, etc. ) Thus, the proposed model estimates only the cost of the economic impact of natural disasters (Formula 9):

$$
C=C_{1}+C_{2}+C_{3}+C_{4}+C_{5}+C_{6}+C_{7}+C_{8}
$$

Taking into account the apparent increase in the economic damage caused by the permanent reduction of the forest area on the planet we can conclude that the cost of each subsequent cutting of the forest increases the size of the economic impact of natural disasters. Therefore, calculating the cost of climate-forming function is suggested to assess based on relations in changes in the value of economic damage over the past decade compared to the previous value of phytomass of forest cutting in the past decade.

Economic evaluation of the impact of the changes that have occurred on the assessed forest area for a certain period (increase or decrease the number of trees) to the formation of the climate of the planet is calculated using the formula 10 :

$$
\mathrm{O} p_{2}=\sum_{k=1}^{v} \frac{C_{t k}-C_{o k}}{\Delta Q_{k}} \Delta q_{k} v k
$$

$\mathrm{O} p_{2}$ - economic valuation of ecosystem service of climate regulation of forest ecosystem, rub; $v$ - the number of years of life of forest ecosystem, years [25, pp. 66, Tables 9, 10; p. 104, Table 35]; $\mathrm{C}_{t k}$ - the total value of economic damage from natural disasters for a $\kappa$-year, rub; $C_{0 \kappa}$ - the total value of economic damage from natural disasters in the year before a $\kappa$-year, rub.; $\Delta Q_{k}-$ phytomass of cutting forests for a $\kappa$-year, ton; $\Delta q_{\mathrm{k}}$ - changes in the total phytomass of all factions on the evaluated area, ton; $v k$ - the share of the contribution of the forest vegetation in the formation of the climate.

The main factors influencing the formation of the climate are [22]:
- changes in the size, topography and relative position of the continents and oceans;

- changes in the luminosity of the sun and solar radiation;

- changes in the parameters of the Earth's orbit and the axis;

- changes in the transparency of the atmosphere and its composition as a result of changes in the Earth's volcanic activity;

- changes in concentrations of greenhouse gases $\left(\mathrm{CO}_{2}\right.$ и $\left.\mathrm{CH}_{4}\right)$ in the atmosphere;

- changes in the reflectivity of the Earth's surface (albedo);

- changes in the amount of heat that presents in the depths of the ocean.

O. G. Sorokhtin [26] identifies the solar radiation, pressure and heat capacity of the Earth's atmosphere as the most important values, however, the majority of these factors are interdependent and some factors cannot be considered in isolation without the influence of others. Vegetation somehow affects all of the factors due to the influence of the composition and the heat capacity of the atmosphere. It shows the complexity of determining its contribution to the formation of climate. A separate study must be done to identify the contribution of each factor. In this study, the proportion of forest vegetation contribution to climate formation has been expertly identified on the level of 0.47 .

Regulation of water by forest ecosystem $p_{3}$

Valuation of ecosystem service of regulation of water by forest ecosystem is suggested in the study employing the income method by using the formula 11. This technique is based on the equation of the water balance of river basins developed by M. I. Lvovich and subsequently finalized by K. N. Dyakonov [25].

$$
\mathrm{O} p_{3}=\Delta S \cdot C_{\mathrm{H}} \cdot \Gamma,
$$

$\mathrm{O} p_{3}$ - economic valuation of ecosystem service of regulation of water by forest ecosystem, rub; $\Delta S$ - the magnitude of groundwater runoff increase in the summer period per 1 ha, thousand $\mathrm{m} 3$ / ha [25, Tables $39,42,45,49] ; \mathrm{C}_{\mathrm{H}}-\operatorname{tax}$ rate for taking water from an underground source, it is 282 rub. per thousand $\mathrm{m} 3$ in 2016 for the Ob River basin; $\Gamma$ - forest area, ha.

Regulation of soil erosion by forest ecosystem $p_{4}$

Economic valuation of against erosion role of forest ecosystem can only be done indirectly by suggesting what harm would bring the erosion if on this place there was no wood, i. e. by employing the method of substitute goods. Taking into account the specific chemical composition of the sediments by determining the hydrological and geochemical properties of the eroded landscape, we should determine how much nitrogen (as a stimulator of plant growth and lengthening of the growing season) is removed by 1 ha of forest each year. Based on the fact that $1 \mathrm{~kg}$ of nitrogen increases the yield of grain crops by $12 \mathrm{~kg}$ [27]. The assessment of ecosystem service of regulation of soil erosion by forest ecosystem is calculated as follows:

$$
\mathrm{O}_{4}=12 Q_{N} \cdot \mathrm{P}_{3 \mathrm{~K}} \cdot \Gamma \text {, }
$$

$\mathrm{O} p_{4}$ - economic valuation of ecosystem service of regulation of soil erosion by forest ecosystem, rub; $12 Q_{N}$ - the number of kilograms of cereals from the certain volume of removed nitrogen per year, $\mathrm{kg}$ of cereals in one year / hectare; $\mathrm{P}_{3 \mathrm{~K}}$ - the price of $1 \mathrm{~kg}$ of cereals, rub. / kg of cereals; $\Gamma$ - forest area, ha.

Purification of water and wastewater by marsh ecosystem $p_{5}$

We evaluate this ecosystem service by employing the method of substitute goods according to the formula 13. For economic evaluation of marsh purification abilities, we compare them with similar abilities of industrial treatment plant with a capacity of $1500 \mathrm{~m}^{3} /$ day. $\left(50-70 \mathrm{~m}^{3}\right.$ of water per hour at 2-3 work shifts).

The price of one industrial treatment plant on average reaches $\$ 50$ thousand. Discounted cost of the industrial treatment plant for one year calculates from the formula of capitalization $P V=Ц_{\text {поу }} / i$ according to which annual discounted cost of the industrial treatment plant ( $\left.Ц_{\text {поу }}\right)$ is defined by employing the formula 13 where $P V$ is the cost of installation, $i$ - interest rate equal to $1 / T$ (years). It is assumed that one industrial treatment plant works at least 50 years, i.e. $T=50, i=0,02$.

$$
\mathrm{O} p_{5}=\frac{S}{\left(\mathrm{P}_{\text {поу }} / \mathrm{P}\right) \times \mathrm{K}_{э}} \times ц_{\Pi о у},
$$

$\mathrm{Op}_{5}$ - economic valuation of ecosystem service of purification of water and wastewater by marsh ecosystem, rub; $\mathrm{S}$ - marsh area, ha; $\mathrm{P}_{\text {поу }}{ }^{-}$capacity of industrial treatment plant, $\mathrm{m}^{3} ; \mathrm{P}$ - capacity of eutrophic bog, $\mathrm{m}^{3} /$ ha (eutrophic bog - $137 \mathrm{~m}^{3} /$ day/ha [27]); $\mathrm{K}_{\ni}$ - efficiency ratio of marshes (eutrophic bog has $\mathrm{K}_{\ni}=1$; mesotrophic bog has $\mathrm{K}_{\ni}{ }_{\ni}=3$; acid bog has $\left.\mathrm{K}_{\ni}=4[15]\right) ; Ц_{\text {поу }}$ - discounted cost of the industrial treatment plant for one year, rub.

Insulation ability by pasture ecosystem $p_{\mathrm{T}}$

Valuation of ecosystem service of insulation ability by pasture ecosystem in the study based on resource evaluation employing the income method by using the formula 14. In the absence of this ecosystem service the ecosystem does not comply with the current functionality.

$$
\mathrm{O} p_{\mathrm{T}}=\mathrm{O}_{3}
$$

$\mathrm{O} p_{\mathrm{T}}$ - economic valuation of ecosystem service of insulation ability by pasture ecosystem, rub; $\mathrm{O}_{3}$ - economic evaluation of pasture, rub. 
11. Depending on the type of ecosystem, indicators can be modified. Cultural services assess as follows:

Spiritual and religious values $\left(\kappa_{1}\right)$

This ecosystem service is the subject to assessment by carrying out surveys on the population's willingness to pay for the preservation of the ecosystem and as a consequence of its spiritual and religious values. tem

Educational values $\left(\kappa_{2}\right)$ and aesthetic values $\left(\kappa_{3}\right)$ from forest ecosys-

These ecosystem services are very closely related and directly dependent on the time spent by a man within the boundaries of a particular ecosystem. On average, every citizen of our country spends in the woods about 52 hours per year [28]. If we assume that the forest "earns" as well as we do, then the evaluation of aesthetic and educational values of the forest can be calculated using the formula:

$$
\mathrm{OK}_{2 \text { из }}=Q_{\text {ч }} \times 3 \Pi \times Q_{\text {H' }},
$$

$\mathrm{OK}_{2{ }_{23}}$ - economic valuation of ecosystem service of educational and aesthetic values from forest ecosystem, rub; $Q_{u}$ - the average number of hours that a person stay in the forest in the country per year, hour/year per person; $3 \Pi$ - the average wage in the country, rub/hour; $Q_{u}$ - population, people.

Recreation and ecological tourism $\left(\mathrm{K}_{4}\right)$ from forest ecosystem

Valuation of ecosystem service of recreation and ecological tourism from the forest ecosystem is suggested in the article employing the income method based on the research [29]. The recreational function from forest ecosystem is to meet the people needs in active recreation, health restoration and, first of all, physical recovery. For the assessment of the recreational service of the forest landscape, we take into account the sustainability of the forest ecosystem to the effects of recreational pressure according to the formula:

$$
\mathrm{O \kappa}_{4}=\sum_{t=1}^{n}\left(8760 \mathrm{~A}_{\text {д }}-3_{\text {л }}\right) \times t_{t},
$$

$\mathrm{OK}_{4}$ - economic valuation of ecosystem service of recreation and ecological tourism from forest ecosystem, rub; A - the average annual allowable (or actual $\mathrm{A}_{\phi}$ ) recreational load in the analyzed area; hour/rub ( 1 year $=8760$ hours); 3 - the annual cost of forest management in the recreational forests, rub. / ha; $t_{t}$ - the duration of the growth of the $i$ - group, years; $n$ - the number of forest age groups (young, middle-aged, ripening, ripe).

Thus, the author's methodical approach allows selecting the most important ecosystems and ecosystem services, representing a simple and serial evaluation algorithm of ecosystem services (environmental resources) on the basis of the concept of total economic value. These guidelines are approved at
Berezovsky District, KhMAD. We have obtained the following results:

1. Analysis of land of Berezovsky District, KhMAD is demonstrated in Table 3 [30].

2. Formation of the structure of land (landscapes) in the analyzed area and an allocation of land (related ecosystems) occupying the largest area in the region is shown in Fig. 3.

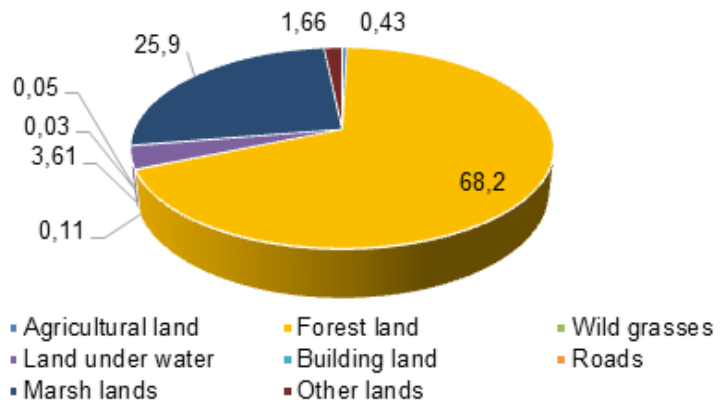

Figure 3. The land structure of of Berezovsky District, KhMAD, \%.

With regard to the study, the forest (68.2\%) and marsh $(25.9 \%)$ and the corresponding ecosystems compose a large part of Berezovsky District, KhMAD, as well as reindeer pastures ( $40.6 \%$ of the total area).

3. Identification of the most important ecosystem services for each defined land (corresponding ecosystem).

The list of the most important ecosystem services for leased lands (forest, marsh, pasture) was determined by the results of the expert survey of ten experts from the Institute of Economics of the Urals Branch of the Russian Academy of Sciences and the Institute of Plant and Animal Ecology of the Ural Branch of the Russian Academy of Sciences. As a result, we have found that for selected lands (ecosystems) there are two most important ecosystem services such as regulation of air quality $\left(p_{1}\right)$ and regulation of water $\left(p_{3}\right)$. For marshes the ecosystem service of purification of water and wastewater $\left(p_{5}\right)$ has been additionally revealed whereas the experts identify the specific insulation ability for pasture ecosystem $\left(p_{\mathrm{r}}\right)$.

4. Economic evaluation of ecosystem services relating to priority.

Reindeer pasture area in Berezovsky District KhMAD locates on forest land (50\% of total forest land) and marsh land (33\% of total marsh land). According to a study [31] forest phytomass is about 150 ton/ha and pastures phytomass is 35 ton/ha. As a result, we obtain the following formulas for the calculation (Table 4).

\begin{tabular}{|c|c|c|c|c|c|c|c|c|c|}
\hline Total area & Agricultural land & Forest land & $\begin{array}{l}\text { Including wooded } \\
\text { land }\end{array}$ & Wild grasses & $\begin{array}{l}\text { Land under } \\
\text { water }\end{array}$ & Building land & Roads & Marsh lands & Other lands \\
\hline \multicolumn{10}{|c|}{ Agricultural lands } \\
\hline 58829 & 10023 & 1918 & 1918 & 6678 & 4587 & 33 & 83 & 32771 & 2736 \\
\hline \multicolumn{10}{|c|}{ Land of inhabited areas } \\
\hline 24575 & 6831 & 2249 & 2249 & 2361 & 3560 & 2339 & - & 6303 & 932 \\
\hline \multicolumn{10}{|c|}{$\begin{array}{l}\text { Land of industry, energy, transportation, communication, radio, } \\
\text { television, earth for space activities, defense, security and other special purposes }\end{array}$} \\
\hline 437 & - & 275 & 275 & - & - & 142 & - & 17 & 3 \\
\hline \multicolumn{10}{|c|}{ Lands of specially protected natural reservations } \\
\hline 59382 & - & 46212 & 44621 & - & 1161 & 21 & 15 & 11973 & - \\
\hline \multicolumn{10}{|c|}{ Designated forest lands } \\
\hline 8075698 & 8277 & 5877396 & 5877396 & - & 86098 & 1960345 & 4329 & 1960345 & 139253 \\
\hline \multicolumn{10}{|c|}{ Water resource lands } \\
\hline 220000 & - & - & - & - & 220000 & - & - & - & - \\
\hline \multicolumn{10}{|c|}{ Reserve lands } \\
\hline 371132 & 12836 & 80560 & 80560 & 500 & 2767 & - & 55 & 270724 & 3690 \\
\hline \multicolumn{10}{|c|}{ Total land within the boundaries of the administrative district } \\
\hline 8810053 & 37967 & 6008610 & 6008610 & 9539 & 318173 & 2535 & 4482 & 2282133 & 146614 \\
\hline
\end{tabular}

Table 3. Analysis of land of Berezovsky District, KhMAD, ha.

Note: Reindeer pasture area of 3578905 hectares locates on forest land; disturbed lands absent (50 \% locates on forest land and $33 \%$ locates on the marsh lands). 
Table 4. The calculation of phytomass of ecosystems, tons

\begin{tabular}{ccc} 
Forest ecosystem & Marsh ecosystem & Pasture ecosystem \\
\hline$(0,5 Y+1,5 X-0,5 Z)$ & $(0,67 Z+1,34 X)$ & $(0,5 Y / 4,3+2,16 X-$ \\
$0,17 Z)$
\end{tabular}

Note: $X=3272,41$ tonnes; $Z$ (See biology/operational reserve of wild grasses in the analyzed area) $=1326,88$ tons; $Y$ (See forest resources of the analyzed in the analyzed area) $=1326,88 \mathrm{tons} ; Y$ (See forest resources of the analyzed
area) $=454430,9$ ths. $\mathrm{m}^{3}=700 \mathrm{~kg} / \mathrm{m}^{3} \cdot 454430900 \mathrm{~m}^{3}=318101630000 \mathrm{~kg}=$ area) $=454430,9$ th
318101,63 tons.

Table 5. Economic evaluation of ecosystem services (ecological resources) of Berezovsky District, KhMAD.

\begin{tabular}{|c|c|c|c|}
\hline Ecosystem & Ecosystem service & Benchmarks & $\begin{array}{l}\text { Economic } \\
\text { evaluation, } \\
\text { ths rub }\end{array}$ \\
\hline \multirow[t]{2}{*}{ Forest } & $\begin{array}{l}\text { Regulation of air quality } \\
p_{1}\end{array}$ & $\begin{array}{c}\sigma_{i}=6008610 \cdot 50 \%= \\
3004305 ; \\
\mathrm{O}_{2 i}=2,2 ; \iota_{0}=10000 ; \\
\mathrm{CO}_{2 i}=3,1 ; \\
p=30 \$ \text { (Dollar } \\
\text { exchange rate on } \\
03.05 .2016 \text { is } 64,63 \\
\text { rub); } Y=318101,63 ; \\
X=3272,41 ; Z=1326,88\end{array}$ & $\begin{array}{l}84152 \\
355,59\end{array}$ \\
\hline & Regulation of water $p_{3}$ & $\begin{array}{c}\Delta S=0,642 ; C_{H}=282 \\
\Gamma=3004305\end{array}$ & 543911,39 \\
\hline \multirow[t]{6}{*}{ Marsh5 } & $\begin{array}{l}\text { Regulation of air quality } \\
p_{1}\end{array}$ & $\begin{array}{l}Z=1326,88 \\
X=3272,41\end{array}$ & $\begin{array}{c}2717 \\
903,88\end{array}$ \\
\hline & $\begin{array}{l}\text { Purification of water } \\
\text { and wastewater } p_{5}\end{array}$ & $\begin{array}{c}S=2282133 \cdot 67 \%= \\
1529029,11 ; \\
P_{\text {поу }}=1500 ; \\
P=137\end{array}$ & $\begin{array}{c}5776 \\
816,73\end{array}$ \\
\hline & & $K_{\ni}=1$ (eutrophic bog); & \\
\hline & & $\begin{array}{c}K_{\ni}=3 \text { (mesotrophic } \\
\text { bog) }\end{array}$ & \\
\hline & & $K_{\ni}=4$ (acid bog) & \\
\hline & & 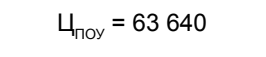 & \\
\hline \multirow[t]{2}{*}{ Pasture } & $\begin{array}{l}\text { Regulation of air quality } \\
p_{1}\end{array}$ & $\begin{array}{c}Y=318101,63 \\
X=3272,41\end{array}$ & $\begin{array}{l}22587 \\
911,43\end{array}$ \\
\hline & Insulation ability $p_{T}$ & $\mathrm{O}_{3}=33466$ & 33466,00 \\
\hline
\end{tabular}

Table 5 shows that ecosystem services of Berezovsky District, KhMAD to May 2016 are estimated at the level of 115,812,365.02 thousand rub. Forest ecosystem provides $73 \%$ of the total value of ecosystem services $(84,696,266.98$ rubles), marsh ecosystem - only $7 \%(8,494,720.61$ rubles $)$, pasture ecosystem $-20 \%$ or $22,621,377.43$ ths rubles.

This article was prepared with the financial support of the Russian Science Foundation. The project number 14-18-00456 «Justification of geographical-ecological-social-and economic approach to the development of natural resource potential of northern poorly known areas within the investment project «Arctic -Central Asia».

\section{REFERENCES}

1. Polnaya entsiklopediya. Available at: http://www.polnaja-jenciklopedija.ru/ geografiya/karty-otsenki-prirodnyh-usloviy-i-resursov-dlya-zhiznedeyatelnosti-cheloveka.html

2. Tishkov A. A. 2002, Ekonomika sokhraneniya bioraznoobraziya [Economy conservation], Moscow, $604 \mathrm{p}$.

3. De Groot R. S. 1987, Environmental functions as a unifying concept for ecology and economics. The Environmentalist, no. 7, pp. 105-109.

4. Westman W. 1977, How much are nature's services worth? Science, pp. 960-964 5. R. Costanza, R. d'Arge, R. de Groot, et al. 1997, The Value of the World's Ecosystem Services and Natural Capital. Nature, vol. 387.

6. Bobylev S. N., Zakharov V. M., 2009, Ekosistemnye uslugi i ekonomika [Ecosystem services and economics], Moscow, $72 \mathrm{p}$.

7. Mel'nik L. G., Degtyareva I. B. 2010, Ekonomicheskaya otsenka i uchet $v$ regional'nom planirovanii ekosistemnykh uslug [Economic evaluation and consideration of regional planning in ecosystem services], 2010. Available at: http:// www.biodiversity.ru/programs/international/teeb/materials_teeb/melnik_degtiareva_TEEB.doc

\section{Вера Васильевна Юрак,}

аспирант

vera_yurak@mail.ru

Уральский государственный горный университет

Россия, Екатеринбург, ул. Куйбышева, 30
8. Mishenin E. V., Oliynik N. V. 2010, Rozvitok rinku ekosistemnikh poslug yak napryamok postkrizovogo zros-tannya ekonomiki Ukraïni [Market development of ecosystem services as the direction of the post-crisis economy of Ukraine]. Mekhanizm regulyuvannya ekonomiki [Mechanism of economic regulation], no. 3, vol. 2, pp. 104-113.

9. Tunitsya Yu. Yu. 2006, Eko-ekonomika i rynok: podolannya superechnostey [Ecological economy and market: overcoming contradictions], $314 \mathrm{p}$.

10. Shapochka N. K., Matsenko A. M. 2010, Ekonomicheskaya otsenka kachestva ekosistemnykh uslug presnoy vody [Economic evaluation of quality of services ecosystem services of pure water]. Materialy soveshchaniya "Proekt TEEB - ekonomika ekosistem i bioraznoobraziya. Perspektivy uchastiya Rossii i drugikh stran NNG" [Materials of the meeting "Project TEEB - Economy ecosystems and biodiversity. Prospects attend Russia and others NIS countries] Available at: http://www.biodiversity.ru/programs/international/teeb/materials_teeb/macenko shapochka_TEEB.doc.

11. 2005, Millennium Ecosystem Assessment. Ecosystems and Human Well-being. Synthesis Report, Island Press, Washington DC, 160 p.

12. Pagiola S., K. von Ritter, Bishop J. 2004, Assessing the Economic Value of Ecosystem Conservation. Environmental Economics Series - World Bank, 2004, 58 p.

13. Bobylev S. N. 1995, Ekonomicheskie problemy bioraznoobraziya: opredelenie vzaimosvyazey (matrichnyy podkhod) [Economic problems of biodiversity: defining the relationship (matrix approach)]. Ekonomika sokhraneniya bioraznnobraziya [Economy conservation of biodiversity], Moscow, pp. 19-25.

14. Girusov E. V., Bobylev S. N., Novoselov A. L., Chepurnykh N. V. 1998, Ekologiya i ekonomika prirodopol'zovaniya [Ecology and environmental economics], Moscow, $519 \mathrm{p}$.

15. Bobylev S. N., Tishkov A. A. 1999, Ekonomicheskaya otsenka bioraznoobraziya [Economic evaluation of biodiversity ]. Global'nyy Ekologicheskiy Fond. Proekt "Sokhranenie bioraznoobraziya» [Global Environment Facility. The project "Biodiversity Conservation"], Moscow, 112 p.

16. Dushin A.V. 2009, Nekotorye aspekty razvitiya teorii tsennosti [Some aspects of the theory of value]. Zhurnal ekonomicheskoy teorii [Russian Journal of Economic Theory], no. 3, pp. 218-222.

17. Serageldin I., Steer A. 1994, Making Development Sustainable: from concept to action. Environmentally Sustainable Development Occasional Paper Series, no. 2 .

18. Balashenko V. V., Ignat'eva M. N., Loginov V. G. 2015, Prirodno-resursnyy potentsial severnykh rayonov: metodicheskie osobennosti kompleksnoy otsenki [Natural resource potential of northern regions: methodological features integrated assessment]. Ekonomika regiona [Economy of region], no. 4, pp. 84-94.

19. Tishkov A.A 2002, Ekonomika sokhraneniya bioraznoobraziya [Economy conservation], Moscow, $604 \mathrm{p}$.

20. 1994, Otchet o nauchno-issledovatel'skoy rabote po teme № 1.93 «Kompleksnaya otsenka zemel' KhMAO» [Scientific report № 1.93 «Complex estimation of KhMAD"], Ekaterinburg, $153 \mathrm{p}$.

21. Voronov M. P., Chasovskikh V. P. 2013, Metodika ekonomicheskoy otsenki sredoformiruyushchikh funktsiy lesa [A method of economic evaluation of environment forming forest functions]. Eko-potentsial [Eco-potential], no. 1-2, pp. 13-23.

22. Kondrat'ev K. Ya., Krapivin V. F., Potapov I. I. 2005, Statistika prirodnykh katastrof [Statistics Disaster]. Problemy okruzhayushchey sredy i prirodnykh resursov: Obzornaya informatsiya [Environment and Natural Resources: Overview], no. 5 , pp. 57-76.

23. Khalilov E. N. 2010, Global Changes of the Environment: Threatening the Progress of Civilization. GEOCHANGE: Problems of Global Changes of the Geological Environment, London, vol. 1, pp. 54-220.

24. Samedzade Z. A., Khalilov E. N. 2011, Natural cataclysms as a global factor of influence on the world economy. Natural Cataclysms and Global Problems of the Modem Civilization. Book of abstracts of the World Forum - International Congress, Istanbul, Turkey. London, $19 \mathrm{p}$.

25. Lebedev Yu. V. 2011, Otsenka lesnykh ekosistem v ekonomike prirodopol'zovaniya [Evaluation of forest ecosystems in environmental economics], Ekaterinburg, $574 \mathrm{p}$.

26. Sorokhtin O. T. 2007, Evolyutsiya klimatov Zemli [The evolution of the earth's climates]. Fizika [Physics], no. 832. Available at: http://fiz. 1 september.ru/article. php ?ID=200700907

27. Antanaytis A. A., Skirstene A. Yu., Shcherbakovayte A. K., Romeykene N. P. 1974, Effektivnost' mineral'nykh udobreniy, vnosimykh pod yachmen', s uchetom soderzhaniy $v$ pochve elementov pitaniya rasteniy $i$ kolichestva osadkov [Proc. Soil Science and Agricultural Chemistry], Vil'nyus, $248 \mathrm{p}$.

28. Rozenberg G. S. 2009, Volzhskiy basseyn: na puti k ustoychivomu razvitiyu [Volga basin: Towards Sustainable Development]. Tol'yatti, 477 p.

29. Lebedev, Yu. V., Kopylova Yu. Yu., Khil'chenko N. V. 2006, Ekologo-ekonomicheskaya otsenka bioraznoobraziya lesnykh ekosistem [Ecological and economic assessment of biodiversity in forest ecosystems]. Ekonomika prirodopol'zovaniya [Environmental Economics], no. 2, pp. 88-111.

30. Eksplikatsiya zemel' Berezovskogo rayona KhMAO. Forma 22-2 na 01.01.2016 g.

31. Perel'man A. I. 1975, Geokhimiya landshafta [Geochemistry of landscape], Moscow, $341 \mathrm{p}$.

Vera Vasil'evna Yurak, postgraduate researcher vera_yurak@mail.ru Ural State Mining University

Ekaterinburg, Russia 